Moh. Masnur, Pramono Hadi \& Srie Juli Rachmawatie, 2021. In Vivo Utilization Of Antagonistic Interaction Abilities Of Biological Agents Against Pathogenic Fungus Of Fusarium spp. For Control Of Stem Rot Disease In The Fig Cuttings (Ficus carica L) And Its Effect On Plant Growth. Journal Viabel Pertanian. (2021), 15(1) 24-31

\title{
IN VIVO UTILIZATION OF ANTAGONISTIC INTERACTION ABILITIES OF BIOLOGICAL AGENTS AGAINST PATHOGENIC FUNGUS OF Fusarium spp. FOR CONTROL OF STEM ROT DISEASE IN THE FIG CUTTINGS (Ficus carica L) AND ITS EFFECT ON PLANT GROWTH
}

\author{
${ }^{1}$ Moh. Masnur, ${ }^{2}$ Pramono Hadi, ${ }^{3}$ Srie Juli Rachmawatie \\ ${ }^{1,2,3}$ Fakultas Pertanian Universitas Islam Batik Surakarta Jawa Tengah Indonesia \\ Email: ${ }^{1}$ mohmasnur.brebes@gmail.com, ${ }^{2}$ ulyaraihan5@gmail.com
}

\begin{abstract}
This study aims to determine the effectiveness of the inoculation of antagonistic biological agents in controlling stem rot disease caused by the pathogenic fungus Fusarium spp., and to increase the growth of fig stem cuttings (Ficus carica L.). This research was conducted at the Greenhouse of the Faculty of Agriculture, Islamic University of Batik Surakarta (UIBS), from September 2020 to December 2020. This study used a completely randomized design (CRD)., with 6 types of treatment, consisting of control, Trichoderma, Gliocladium, Corynebacterium, PGPR, and synthetic fungicide Mancozeb as a comparison, with 3 repetitions and 3 subrepetitions. Observations consisted of several parameters, namely: disease incubation period, disease incidence, disease severity, shoot growth period, shoot height, leaf number, leaf area, root length, and number of roots. The results showed that Trichoderma treatment gave the best results for all observed parameters, even better than Mancozeb which is usually used by farmers. This is because Trichoderma has the ability of antagonistic in the form of very aggressive competition, producing antibiotic, and mycoparasitic mechanism against the pathogenic fungus Fusarium spp., so its utilization can be applied in organic farming to control stem rot disease which is more environmentally friendly. Trichoderma can also be used as biofertilizer because it has the ability as a good biodecomposer, its can breakdown nitrogen nutrients, dissolve phosphate, and provide micro nutrients, and even release the hormones auxin, cytokinins and ethylene, so that its effectiveness can stimulate and increase vegetative growth of fig plants in the form of shoots, leaves and roots.
\end{abstract}

Keywords: fig, Fusarium spp., biological agent, Trichoderma, Mancozeb

\section{PENDAHULUAN}

Tanaman tin (fig) merupakan tanaman endemik dari wilayah Asia Barat dan Eropa Selatan, dan masih termasuk kerabat tanaman hias karet kebo (rubber fig) karena berasal dari genus yang sama, yaitu Ficus, dan dari suku yang sama, yaitu Moraceae, sehingga menurut Rosanti (2013) buah tin merupakan buah semu, karena buahnya berasal dari bagian-bagian bunga yang turut berkembang, seperti halnya anggota suku Moraceae lainnya. Buah tin dalam Bahasa Indonesia disebut sebagai "buah ara" dan mempunyai nama lain sebagai "buah surga". Menurut Khariruddin (2015) buah tin adalah makanan untuk para penduduk surga bagi penganut kepercayaan Islam. Namun, buah tin juga disebutkan dalam kitab-kitab berbagai agama, seperti halnya Buddha, Hindu, Kristen, Yahudi, dan kitab agama Islam itu sendiri, yakni dijadikannya buah tin sebagai nama surat dalam kitab Al-Qu'ran, yaitu surat At-Tin, sehingga memberikan isyarat bahwa di dalam buah tin mengandung banyak manfaat. Bahkan, Rasulullah SAW dalam suatu riwayat pernah berkata kepada para sahabat bahwa, "buah (tin) ini (memiliki) banyak 
Moh. Masnur, Pramono Hadi \& Srie Juli Rachmawatie, 2021. In Vivo Utilization Of Antagonistic Interaction Abilities Of Biological Agents Against Pathogenic Fungus Of Fusarium spp. For Control Of Stem Rot Disease In The Fig Cuttings (Ficus carica L) And Its Effect On Plant Growth. Journal Viabel Pertanian. (2021), 15(1) 24-31

sekali manfaatnya untuk badan". Hal tersebut diperkuat oleh hasil penelitian Patil et al. (2010) dalam Rahmah \& Pujiastuti (2016), bahwa buah dan daun tin bekerja sebagai imunomodulator, sehingga mampu meningkatkan sistem imun dalam tubuh. Buah dan daun tin mampu menghancurkan masuknya mikroba ke dalam tubuh, dimana mikroba tersebut dapat menyebabkan penyakit, sehingga infeksi penyakit akibat mikroba tersebut dapat dicegah dengan mengkonsumsi buah dan daun tin ini.

Berdasarkan hal tersebut, buah tin dapat menjadi buah yang sangat potensial di masa depan, sehingga perlu dilakukannya pembiakan tanaman agar produksi buah tin dapat meningkat dari sebelumnya. Upaya tersebut dilakukan untuk mendukung rencana aksi global dalam agenda SDG's 2030 (Sustainable Development Goals) yang memiliki 17 tujuan akhir, di mana salah satu tujuannya menurut Joga (2017) adalah tercapainya ketahanan pangan dan peningkatan gizi, sehingga mampu meningkatkan kesehatan dan kesejahteraan masyarakat.

Pembiakan tanaman tin dapat dilakukan dengan pembiakan generatif maupun vegetatif, tetapi sangat disarankan menggunakan teknik pembiakan vegetatif, karena menurut Duaja et al. (2020), tanaman hasil pembiakan vegetatif akan lebih cepat berbuah sehingga produksi dapat meningkat lebih cepat daripada pembiakan generatif yang butuh waktu lama untuk berbuah. Hal tersebut karena pembiakan vegetatif adalah pembiakan aseksual yang berlangsung dengan cara pelepasan bagian vegetatif dari tanaman induknya, berupa batang, daun, atau akar, yang kemudian tumbuh menjadi tanaman baru, dan berlangsung tanpa perubahan susunan genetika, sehingga sifat tanaman baru tersebut akan sama sifatnya dengan tanaman induknya. Pembiakan vegetatif tersebut dapat dilakukan melalui teknik okulasi, cangkok, kultur jaringan, dan stek.

Tanaman tin memiliki jaringan kambium pada batangnya, sehingga menurut Flaishman et al (2008) dalam Rahmah dan Pujiastuti (2016) menyatakan bahwa tanaman tin dapat diperbanyak secara vegetatif melalui teknik penyetekan pada batang. Namun, berdasarkan wawancara dan observasi yang peneliti lakukan terhadap petani pembudidaya bibit tin di Karanganyar, Semarang, Bandung, Bekasi, dan Jakarta, mereka memiliki keluhan yang sama terhadap stek, yaitu banyak terjadi kegagalan pada hasil penyetekan. Kegagalan tersebut diakibatkan oleh serangan penyakit busuk batang yang disebabkan oleh patogen.

Hasil isolasi patogen yang dilakukan Jahén-Rivera (2020), menyatakan bahwa fungi patogenik dari genus Fusarium spp merupakan salah satu penyebab dari serangan penyakit busuk pada batang tin tersebut. Bahkan, Fusarium spp. dilaporkan sering menyerang beberapa komoditas tanaman sehingga mengakibatkan kerugian yang sangat besar, karena menurut Leslie \& Summerell (2016) dalam Jahén-Rivera (2020), fungi patogenik Fusarium spp. tersebut menghasilkan enzim yang mampu mendegradasi fitoaleksin, seperti enzim kutinase, selulase, kitosanase, pektinase, dan lainnya, sehingga dapat menyebabkan kelayuan pada jaringan pengangkut (vascular wilt) serta pembusukan pada batang dan akar. Berbagai usaha untuk mengendalikan penyakit busuk batang pada stek tin telah banyak dilakukan, bahkan menurut Kardinan (2016) petani biasanya menggunakan cara kimiawi yaitu dengan mengaplikasikan pestisida sintetik berbahan aktif Mancozeb karena lebih cepat dan spesifik, namun berbahaya bagi manusia dan lingkungan, bahkan dapat menyebabkan resistensi patogen. Hal tersebut karena penggunaan Mancozeb secara terus- menerus dapat mengakibatkan peningkatan intensitas serangan penyakit, dan juga dapat mengakibatkan penurunan populasi mikroba antagonis. Pengendalian penyakit yang lebih ramah lingkungan dapat memanfaatkan bahan-bahan yang tersedia dari alam.

Hal tersebut menurut BSN (2016) dalam Kardinan (2016) sesuai dengan kaidah sistem pertanian organik SNI 6729:2016, di mana bahan-bahan yang diperbolehkan untuk 
Moh. Masnur, Pramono Hadi \& Srie Juli Rachmawatie, 2021. In Vivo Utilization Of Antagonistic Interaction Abilities Of Biological Agents Against Pathogenic Fungus Of Fusarium spp. For Control Of Stem Rot Disease In The Fig Cuttings (Ficus carica L) And Its Effect On Plant Growth. Journal Viabel Pertanian. (2021), 15(1) 24-31

pengendalian penyakit adalah salah satunya dengan memanfaatkan mikroba dari alam seperti virus, jamur, protozoa, nematoda, bakteri, dan mikroba lainnya. Mikroba tersebut dijuluki sebagai agens hayati, karena memiliki sifat antagonis. Antagonis menrut Rifai et $a l$, (2020) berarti bahwa apabila suatu mikroba mampu menekan mikroba lainnya, sehingga menghasilkan suatu interaksi yang antagonistik.

Menurut Kusnadi et al., (2013), interaksi antagonistik muncul dalam suatu bentuk hubungan asosial, di mana apabila mikroba A dan mikroba B menempati suatu habitat yang sama, maka akan memberikan efek berupa kompetisi antar mikroba untuk memperoleh nutrisi dan ruang yang sama dari lingkungan hidupnya, sehingga akan ada mikroba yang tertekan pertumbuhannya, dan ada mikroba yang lulus hidup serta dapat berkembangbiak, sehingga mampu menguasai ruang. Interaksi antagonistik tersebut biasanya terjadi pada agens hayati terhadap patogen, melalui mekanisme kompetitif, antibiotik, dan parasitistik.

Pemanfaatan agens hayati dalam pengendalian penyakit sudah banyak yang meneliti dan mempublikasikan hasilnya. Hasil penelitian Juariyah \& Sinaga (2018) melaporkan bahwa penggunaan agens hayati Trikoderma (Trichoderma spp.) dan Gliokladia (Gliocladium spp.) mampu menghambat infeksi Fusarium spp. secara in vivo pada bibit kelapa sawit. Kemudian, Nuryani et al. (2018) melaporkan bahwa penggunaan agens hayati Korinebakteria (Corynebacterium spp.) dan Rizobakteria (PGPR) mampu mengendalikan penyakit karat Fusarium spp. pada tanaman krisan. Namun, belum ada penelitian tentang pemanfaatan agens hayati tersebut dalam pengendalian penyakit busuk batang Fusarium spp. pada tanaman tin (Ficus carica L).

\section{METODE PENELITIAN}

Penelitian dilaksanakan di Greenhouse Fakultas Pertanian Universitas Islam Batik Surakarta (UIBS), dari 15 September 2020 sampai dengan 23 Desember 2020. Alat yang digunakan meliputi: pruning shears, cangkul, ember, sekop mini, terpal, tali, karung, polybag 12x12, kayu, pisau, kawat, paranet, kertas saring, gelas ukur, petridish, glass test tube, dan alat ukur. Bahan yang digunakan meliputi: batang tin, agens hayati (Trikoderma, Gliokladia, Korinebakteria, dan Rizobakteria), Mankozeb, EM-4, air, kotoran sapi, gula aren, serbuk gergaji kayu, tanah, sekam mentah, alkohol, isolat Fusarium spp., aquadesh, agar dekstrosa kentang, dan kloroks.

Penelitian dilakukan secara eksperimental in vivo yang disusun secara non-faktorial menggunakan Rancangan Acak Lengkap (RAL) dengan 6 jenis perlakuan yang terdiri atas: A0 (kontrol), A1 (Trikoderma), A2 (Gliokladia), A3 (Korinebakteria), A4 (Rizobakteria), dan A5 (Mankozeb sebagai pembanding), yang diulang 3 kali, dan memiliki 3 subulangan. Pelaksaan penelitian terdiri atas isolasi dan pembiakan fungi patogenik Fusarium spp., pembuatan pupuk organik, persiapan penyetekan, penanaman bahan stek, dan inokulasi perlakuan.

Isolat fungi patogenik Fusarium spp. didapatkan dengan cara mengisolasi batang tin yang sakit di Kebun Tin Watusambang (Karanganyar), kemudian diperbanyak di Laboratorium Pengamatan Hama dan Penyakit Palur (Sukoharjo). Caranya adalah bagian batang yang sakit dipotong-potong dan direndam dalam larutan kloroks lalu dicuci dengan aquadesh dan dikeringkan di atas kertas sterile filtration, kemudian potongan tersebut dibiakkan pada media agar dekstrosa kentang hingga hifa miselium tumbuh, selanjutnya mengisolasi kembali untuk mendapatkan biakan murni, selanjutnya melakukan pembiakan biakan tersebut dalam petridish hingga panen, kemudian biakan dimasukkan sporanya ke dalam glass test tube.

Pembuatan pupuk organik dilakukan di Wonorejo (Sragen) dengan memanfaatkan limbah peternakan sapi, yang didekomposisi menggunakan bantuan mikroba aktivator 
Moh. Masnur, Pramono Hadi \& Srie Juli Rachmawatie, 2021. In Vivo Utilization Of Antagonistic Interaction Abilities Of Biological Agents Against Pathogenic Fungus Of Fusarium spp. For Control Of Stem Rot Disease In The Fig Cuttings (Ficus carica L) And Its Effect On Plant Growth. Journal Viabel Pertanian. (2021), 15(1) 24-31

kompos (EM-4) dengan nutrisi dari gula aren. Siapkan kotoran sapi dan ditumpuk secara membentuk lapisan dengan ketebalan tiap lapisan sekitar 20-30 cm. Siapkan 20 liter air di dalam ember dan campurkan $100 \mathrm{ml}$ EM-4 dengan 3 liter larutan gula aren matang, kemudian siramkan pada setiap lapisan secara merata, demikian seterusnya hingga ketebalan lapisan mencapai $1 \mathrm{~m}$. Jika sudah merata, masukkan ke dalam karung dan biarkan inkubasi selama 1 bulan atau hingga terfermentasi maksimal. Jika sudah terfermantasi, lakukan sterilisasi media tanam dengan cara menjemur di bawah terik matahari selama 1 minggu.

Bahan stek diambil dengan cara memotong ranting dengan pruning shears dari pohon induk tin berumur 5 tahun di Kebun Tin Tulakan (Karanganyar), kemudian ranting yang terpotong tersebut dilakukan penyetekan (cutting) dengan ukuran $15 \mathrm{~cm}$, dan ujungnya dipotong miring $45^{\circ}$ untuk dijadikan bahan stek. Bahan stek yang telah siap selanjutnya dapat ditanam dalam media tanam. Media tanam yang digunakan adalah pupuk organik sapi, tanah, serbuk gergaji kayu, dan sekam mentah, dengan perbandingan 1:1:2:2. Sebelum ditanam, bahan stek dan media tanam dilakukan infestasi penyakit dan inokulasi agens hayati. Setelah ditanam, aplikasikan perlakuan agens hayati dengan cara mengocorkan larutan perlakuan sesuai dosis rekomendasi pada interval inokulasi agens hayati 1 minggu sekali selama 8 minggu. Agens hayati tersebut didapatkan dari CV. Prapdita Paramita Solo dalam bentuk formulasi inokulum serbuk. Selanjutnya dapat dilakukan pemeliharaan dengan cara penyiraman air dalam interval 3 hari sekali. Kemudian dilakukan pengamatan untuk pengambilan data pada tanaman percobaan dari awal pengamatan hingga akhir pengamatan, yaitu 56 hst.

Parameter pengamatan meliputi: periode inkubasi penyakit (hsi), insidensitas penyakit $(\%)$, severitas penyakit $(\%)$, periode tumbuh tunas (hst), tinggi tunas $(\mathrm{cm})$, jumlah daun (helai), luas daun, $\left(\mathrm{cm}^{2}\right)$, panjang akar $(\mathrm{cm})$, dan jumlah akar (buah). Data hasil pengamatan dilakukan transformasi data, kemudian hasil transformasi dilakukan uji statistik menggunakan analysis of variance (uji F) pada taraf 5\% dan 1\%, dan dilanjutkan dengan uji Duncan pada taraf 5\% apabila ada beda nyata maupun beda sangat nyata.

\section{HASIL PENELITIAN}

Hasil penelitian menunjukkan bahwa inokulasi agens hayati dapat menekan periode inkubasi penyakit (PIP), insidensitas penyakit (IP), dan severitas penyakit (SP) pada stek batang tanaman tin (Ficus carica L.) secara in vivo (tabel 1).

Tabel 1. Pengaruh pengaruh agens hayati terhadap serangan penyakit akibat Fusarium spp.

\begin{tabular}{|l|c|c|c|}
\hline Perlakuan & PIP & IP & SP \\
\hline Kontrol & $5,33 \mathbf{a}$ & $10,02 \mathrm{~b}$ & $10,02 \mathbf{b}$ \\
\hline Trikoderma & $48,89 \mathbf{d}$ & $2,41 \mathrm{a}$ & $1,37 \mathbf{a}$ \\
\hline Gliokladia & $39,56 \mathbf{c}$ & $5,70 \mathrm{a}$ & $2,72 \mathbf{a}$ \\
\hline Korinebakteria & $31,89 \mathbf{b}$ & $6,92 \mathrm{a}$ & $3,91 \mathbf{a}$ \\
\hline Rizobakteria & $46,56 \mathbf{d}$ & $3,21 \mathrm{a}$ & $1,71 \mathbf{a}$ \\
\hline Mankozeb & $43,56 \mathbf{c d}$ & $4,91 \mathrm{a}$ & $2,99 \mathbf{a}$ \\
\hline
\end{tabular}

Keterangan: angka-angka yang diikuti huruf yang sama pada garis atau kolom yang sama tidak berbeda nyata pada uji jarak berganda Duncan (DMRT) pada taraf 5\%.

Berdasarkan tabel 1, dari hasil percobaan yang dilakukan terhadap fungi patogenik Fusarium spp. yang diinokulasikan pada batang tin dan media, dengan aplikasi inokulasi berbagai perlakuan beberapa jenis agens hayati antagonistik, menunjukkan bahwa semua perlakuan inokulasi agens hayati, baik itu agens hayati Trikoderma (Trichoderma spp.), 
Moh. Masnur, Pramono Hadi \& Srie Juli Rachmawatie, 2021. In Vivo Utilization Of Antagonistic Interaction Abilities Of Biological Agents Against Pathogenic Fungus Of Fusarium spp. For Control Of Stem Rot Disease In The Fig Cuttings (Ficus carica L) And Its Effect On Plant Growth. Journal Viabel Pertanian. (2021), 15(1) 24-31

Gliokladia (Gliocladium spp.), Korinebakteria (Corynebacterium spp.), dan Rizobakteria (PGPR), terbukti mampu menekan infeksi fungi patogenik Fusarium spp, bahkan hasilnya lebih baik daripada kontrol dan pembanding.

Hasil tersebut menunjukkan bahwa perlakuan beberapa agens hayati yang diinokulasikan, terbukti memiliki kemampuan interaksi antagonistik terhadap fungi patogenik. Menurut Farida (1992) dalam Kusnadi (2013), interaksi antagonistik agens hayati tersebut adalah dengan interaksi kompetitif, antibotik, dan mikoparasitik, sehingga efektif dalam menghambat pertumbuhan fungi patogenik Fusarium spp dalam satu ekosistem. Namun, interaksi antagonistik dari masing-masing agens hayati akan memberikan efikasi yang berbeda, dan hal itu dipengaruhi oleh zat antibiotik yang dihasilkan, serta kemampuan kompetisi kecepatan tumbuh oleh setiap agens hayati.

Hasil penelitian menunjukkan bahwa perlakuan terbaik diperoleh pada agens hayati Trikoderma (Trichoderma spp.). Hal tersebut menandakan bahwa Trikoderma mampu mengendalikan serangan fungi patogenik Fusarium spp. penyebab penyakit busuk batang pada stek batang tanaman tin. Sehingga dapat disimpulkan bahwa, Trikoderma memiliki interaksi antagonistik yang lebih potensial daripada agens hayati lainnya. Bahkan hasilnya lebih baik daripada Mankozeb, cara yang biasanya dilakukan oleh petani.

Hal tersebut sesuai dengan pernyataan Baker dan Cook (1982), bahwa Trikoderma memiliki interaksi antagonistik terhadap fungi patogenik dengan kemampuannya yang mampu berkompetisi secara agresif sehingga cepat menguasai ruang, kemampuan amensalisme yang dapat mengakibatkan lisis, dan juga kemampuan mekanisme mikoparasitik. Trikoderma dapat tumbuh sangat cepat dan mampu mengungguli pertumbuhan fungi patogenik Fusarium spp. sehingga dapat mengkolonisasi tempat dan nutrien secara agresif. Sehingga, inokulasi Trikoderma ke dalam suatu medium, dapat menyebabkan ledakan populasi mikroba antagonistik tersebut di dalam mediumnya, kemudian akan terjadi penghambatan pertumbuhan bagi fungi patogenik yang berakibat pada tingginya tingkat mortalitas fungi patogenik. Sehingga dengan kemampuan interaksi antagonistik tersebut, Trikoderma mampu menekan periode inkubasi penyakit dengan hasil terlambat (48), menekan insidensitas penyakit dengan hasil terkecil $(2,41)$, dan menekan severitas penyakit dengan hasil terkecil $(1,37)$.

Hasil yang sama juga disampaikan oleh penelitian Maulida (2020), bahwa Trikoderma mampu memperlambat masa inkubasi penyakit dan dapat mengendalikan serangan penyakit moler yang disebabkan oleh Fusarium spp. Baker dan Cook (1982) menyatakan bahwa kemampuan antagonistik Trikoderma dalam menekan fungi patogenik pada umumnya adalah melalui interaksi mikoparasitik dan kompetisi yang agresif. Mulamula hifa Trikoderma tumbuh memanjang, kemudian menempel dan melilit hifa fungi patogenik, sehingga struktur hifa patogen tersebut mengalami kerusakan membran sel, kosongnya isi sel, dan akhirnya Trikoderma tumbuh di dalam hifa fungi patogenik Fusarium spp. Lebih lanjut, kemampuan mikoparasitik tersebut disebabkan karena Trikoderma mampu menghasilkan senyawa antibiosis berupa metabolit sekunder yang dapat menguap maupun tidak dapat menguap, sehingga mampu menghancurkan $\beta$ glucan dan chitine yang merupakan komponen dinding hifa fungi patogenik Fusarium spp, sehingga menghambat kolonisasi patogen karena lisis dan vakoulasi.

Selain itu, inokulasi agens hayati antagonistik juga memberikan pengaruh yang sangat signifikan terhadap respons semua parameter pertumbuhan vegetatif stek batang tin (tabel 2.), yaitu respons periode muncul tunas (PMT), tinggi tunas (TT), jumlah daun (JD), luas daun (LD), panjang akar (PA), dan jumlah akar (JA). Berdasarkan tabel 2, dari percobaan yang dilakukan terhadap stek batang tin (Ficus carica L.) menunjukkan bahwa perlakuan terbaik yang mampu meningkatkan pertumbuhan vegtatif tanaman diperoleh pada inokulasi inokulan agens hayati antagonistik Trikoderma, dengan hasil nilai periode 
Moh. Masnur, Pramono Hadi \& Srie Juli Rachmawatie, 2021. In Vivo Utilization Of Antagonistic Interaction Abilities Of Biological Agents Against Pathogenic Fungus Of Fusarium spp. For Control Of Stem Rot Disease In The Fig Cuttings (Ficus carica L) And Its Effect On Plant Growth. Journal Viabel Pertanian. (2021), 15(1) 24-31

muncul tunas $(6,56)$, tinggi tunas $(3,30)$, jumlah daun $(3,01)$, luas daun $(20,13)$, panjang akar $(3,24)$ dan jumlah akar $(4,74)$.

Tabel 2. Pengaruh pengaruh agens hayati terhadap pertumbuhan stek tanaman tin

\begin{tabular}{|l|l|l|l|l|l|l|}
\hline Perlakuan & \multicolumn{1}{|c|}{ PMT } & TT & JD & LD & PA & JA \\
\hline Kontrol & $56,00 \mathbf{d}$ & $0,71 \mathbf{a}$ & $0,71 \mathbf{a}$ & $0,71 \mathbf{a}$ & $0,71 \mathbf{a}$ & $0,71 \mathbf{a}$ \\
\hline Trikoderma & $6,56 \mathbf{a}$ & $3,30 \mathbf{e}$ & $3,01 \mathbf{e}$ & $20,13 \mathbf{e}$ & $3,24 \mathbf{d}$ & $4,74 \mathbf{e}$ \\
\hline Gliokladia & $13,11 \mathbf{b}$ & $2,64 \mathbf{c}$ & $2,43 \mathbf{c}$ & $14,25 \mathbf{c}$ & $2,17 \mathbf{b}$ & $2,89 \mathbf{c}$ \\
\hline Korinebakteria & $14,00 \mathbf{b}$ & $2,67 \mathbf{c}$ & $2,39 \mathbf{c}$ & $15,04 \mathbf{c}$ & $2,10 \mathbf{b}$ & $2,61 \mathbf{b c}$ \\
\hline Rizobakteria & $9,22 \mathbf{a}$ & $2,97 \mathbf{d}$ & $2,75 \mathbf{d}$ & $18,44 \mathbf{d}$ & $2,70 \mathbf{c}$ & $4,42 \mathbf{d}$ \\
\hline Mankozeb & $30,33 \mathbf{c}$ & $1,83 \mathbf{b}$ & $1,95 \mathbf{b}$ & $9,56 \mathbf{b}$ & $1,23 \mathbf{a}$ & $2,01 \mathbf{b}$ \\
\hline
\end{tabular}

Keterangan : angka-angka yang diikuti huruf yang sama pada garis atau kolom yang sama tidak berbeda nyata pada uji jarak berganda Duncan (DMRT) pada taraf 5\%.

Menurut Herlina dan Dewi (2010), Trikoderma dapat berperan sebagai biodekomposer yang baik, sehingga mampu mendekomposisi unsur hara yang terdapat dalam media tanam berupa pupuk organik sapi yang mempunyai kandungan hara makro maupun mikro, sehingga hara tersebut dapat diserap oleh tanaman. Trikoderma dapat berfungsi untuk memecah kandungan senyawa organik kompleks, sehingga hara makro seperti fosfat, sulfur, nitrogen, dan kalium yang terdapat dalam senyawa kompleks mampu terserap oleh tanaman, dimana salah satu hara makro tersebut, yaitu nitrogen, dimanfaatkan tanaman untuk merangsang pertumbuhan vegetatif tanaman berupa pembentukan daun, batang, dan akar.

Barroso et al. (2006) dalam Katriani (2013) juga melaporkan bahwa Trikoderma mampu untuk melarutkan fosfat anorganik yang tidak dapat diserap oleh tanaman, sehingga bisa diserap oleh tanaman untuk pertumbuhan dengan mengubah menjadi bentuk fosfat organik, di mana fosfat organik dibutuhkan tanaman untuk proses metabolisme. Bahkan, penelitian Arazarmi et al. (2011) dalam Katriani (2013) juga membuktikan bahwa inokulasi Trikoderma pada tanah atau media tanam dapat meningkatkan konsentrasi hara mikro seperti $\mathrm{Ca}^{2+}, \mathrm{Mg}^{2+}, \mathrm{P}, \mathrm{Na}^{+}$dan $\mathrm{K}^{+}$. Lebih dari itu, penelitian Shukla (2012) dalam Katriani (2013) juga melaporkan bahwa aplikasi Trikoderma memberikan pengaruh positif terhadap respon biokimia dan morfofisiologis tanaman pada cekaman kekeringan.

Selain hal-hal yang disebutkan diatas, Chamzurni (2011) melaporkan bahwa Trikoderma mampu menghasilkan IAA (fitohormon auksin). Lebih lanjut, Trikoderma juga dapat menghasilkan fitohormon sitokinin, auksin, dan etilen yang dapat dimanfaatkan oleh tanaman secara maksimal karena fungsi dari fitohormon tersebut adalah dapat merangsang dan memacu proses percepatan pertumbuhan vegetatif tanaman, sehingga Trikoderma dapat dimanfaatkan sebagai pupuk hayati yang lebih ramah lingkungan daripada penggunaan pupuk kimiawi sintesis. Hal tersebut juga dibuktikan oleh penelitian Nuraufan (2021) yang menyatakan bahwa aplikasi inokulasi Trikoderma dapat memberikan efek peningkatan pertumbuhan vegetatif tanaman seperti tunas, akar, dan daun stek batang kelor (Moringa oleifera $\mathrm{L}$ ).

\section{KESIMPULAN}

Hasil penelitian yang dilakukan dapat disimpulkan bahwa:

1. Agens hayati Trikoderma mampu menekan periode inkubasi penyakit, insidensitas penyakit, dan severitas penyakit. Hal tersebut karena Trikoderma memiliki kemampuan antagonistik terhadap fungi patogenik Fusarium spp. melalui interaksi 
Moh. Masnur, Pramono Hadi \& Srie Juli Rachmawatie, 2021. In Vivo Utilization Of Antagonistic Interaction Abilities Of Biological Agents Against Pathogenic Fungus Of Fusarium spp. For Control Of Stem Rot Disease In The Fig Cuttings (Ficus carica L) And Its Effect On Plant Growth. Journal Viabel Pertanian. (2021), 15(1) 24-31

kompetitif, antibiotik, dan mikoparasitik, dengan demikian Trikoderma dapat dimanfaatkan untuk pengendalian penyakit busuk batang pada tin, serta digunakan sebagai pengganti cara kimawi yang biasa dilakukan petani, sehingga lebih ramah lingkungan dan organik.

2. Peningkatan pertumbuhan vegetatif tanaman disebabkan karena peranan Trikoderma sebagai biodekomposer yang baik, sehingga hara dapat diserap oleh tanaman, terutama penyediaan hara nitrogen, fosfat, dan hara mikro. Selain itu, Trikoderma juga memproduksi hormon auksin, etil, dan sitokinin, sehingga dapat memacu pertumbuhan tanaman stek batang tin.

\section{UCAPAN TERIMA KASIH}

Ucapan terima kasih dari penulis disampaikan kepada Dekan Fakultas Pertanian Universitas Islam Batik Surakarta untuk dukungan penelitian yang telah diberikan melalui program Penelitian Dosen tahun anggaran 2020, dan kepada Ketua Lembaga Penelitian Pengembangan dan Pengabdian Pada Masyarakat Universitas Islam Batik Surakarta yang telah memfasilitasi dan memberikan dukungan penuh sehingga penelitian ini dapat terlaksana dengan lancar dan baik.

\section{DAFTAR PUSTAKA}

Baker, K. F., dan Cook, R. J. 1982. Biological Control of Plant Pathogens. American Phytopathology Society Press and Publishing. Minnessota. USA.

Chamzurni, T., Sriwati, R., dan Selian, R.D 2011. Efektivitas Dosis dan Waktu Aplikasi Trichoderma virens terhadap Serangan Sclerotium rolfsii pada Kedelai. Jurnal Floratek. 6(1): 62-73.

Duaja, M. D., Kartika, E., dan Gusniwati. 2020. Pembiakan Tanaman Secara Vegetatif.

Penerbit Fakultas Ekonomi dan Bisnis Universitas Jambi, Jambi.

Herlina, L., dan P. Dewi. 2010. Penggunaan Kompos Bahan Aktif Trichoderma harzanium dalam Meningkatkan Pertumbuhan Tanaman Cabai. Jurnal Sains dan Teknologi. 8(2): 11-25.

Jahén-Rivera, S. N., Gómez-Rodríguez, O., dan Espinosa-Victoria, D. 2020. Isolation and Identification of Pathogens Causing Stem Rot of the Fig Tree (Ficus carica). Mexican Journal of Phytopathology. 38(2): 1-11

Joga, N. 2017. Mewariskan Kota Layak Huni. Penerbit Gramedia. Jakarta.

Juariyah, S., Tondok, E. T. dan Sinaga, M. S. 2018. Trichoderma dan Gliocladium untuk Mengendalikan Penyakit Busuk Akar Fusarium pada Bibit Kelapa Sawit (Elaeis guineensis Jacq). Jurnal Fitopatologi Indonesia. 14(6): 196-204.

Kardinan, A. 2016. Sistem Pertanian Organik: Falsafah, Prinsip, Inspeksi. Penerbit Intimedia. Malang.

Katriani, M. 2013. Analisis Morfofisiologi dan Hasil Jagung yang Diaplikasikan Trichoderma spp dan NPK pada Lahan Kering. Disertasi. Program Pascasarjana Universitas Hasanuddin, Makassar.

Khariruddin. 2015. Morfologi dan Anatomi Buah dalam Al-Qur'an. Skripsi. Fakultas Ushuluddin dan Humanoria Universitas Islam Negeri Walisongo, Semarang.

Kusnadi, Hamdiyati, Y., dan Fitriani, A. 2003. Mikrobiologi. Penerbit FMIPA 
Moh. Masnur, Pramono Hadi \& Srie Juli Rachmawatie, 2021. In Vivo Utilization Of Antagonistic Interaction Abilities Of Biological Agents Against Pathogenic Fungus Of Fusarium spp. For Control Of Stem Rot Disease In The Fig Cuttings (Ficus carica L) And Its Effect On Plant Growth. Journal Viabel Pertanian. (2021), 15(1) 24-31

Universitas Pendidikan Indonesia, Bandung.

Maulida, N. K. 2020. Uji Keefektifan Tiga Isolat Trichoderma harzianum terhadap Penyakit Moler Bawang Merah In Planta. Skripsi. Fakultas Pertanian Universitas Jenderal Soedirman, Purwokerto.

Nuraufan, F. R. 2021. Pertumbuhan Stek Tanaman Kelor (Moringa oleifera Lam.) terhadap Waktu Inokulasi Trichoderma dan Berbagai Level Pupuk Limbah Baglog. Skripsi. Fakultas Pertanian UPNV Yogyakarta, Yogyakarta.

Nuryani, W., Silvia, E., Hanudin, dan Budiarto, K. 2018. Aplikasi Biofungisida Berbahan Aktif Corynebacterium sp. Ramah Lingkungan dalam Pengendalian Penyakit Karat Putih pada Krisan. Jurnal Teknologi Lingkungan. 19(1): 23-32.

Rahmah, D. S., dan Pujiastuti, E. 2016. Prospek Bisnis Buah Tin. Penerbit Trubus Swadaya, Jakarta.

Rifai, M. R., Widowati, H., dan Sutanto, A. 2020. Sinergisme dan Antagonisme Beberapa Jenis Isolat Bakteri yang Dikonsursiumkan. Jurnal BIOLOVA. 1(1): 21-26.

Rosanti, D. 2013. Morfologi Tumbuhan. Penerbit Erlangga, Jakarta. 